\title{
"Demand for charcoal among petty traders in Oyo state, Nigeria: a paradox of survival and environmental degradation"
}

Fatai Abiola Sowunmi (D http://orcid.org/0000-0002-7555-0299

AUTHORS

Adewumi Oyewunmi Oyebanjo

Osarobo Cecil Omigie

Zakariyah Olayiwola Amoo

Fatai Abiola Sowunmi, Adewumi Oyewunmi Oyebanjo, Osarobo Cecil Omigie

ARTICLE INFO and Zakariyah Olayiwola Amoo (2018). Demand for charcoal among petty traders in Oyo state, Nigeria: a paradox of survival and environmental degradation.

Environmental Economics, 9(2), 36-46. doi:10.21511/ee.09(2).2018.03

DOI

http://dx.doi.org/10.21511/ee.09(2).2018.03

RELEASED ON

Monday, 25 June 2018

RECEIVED ON

Friday, 09 March 2018

ACCEPTED ON

Wednesday, 20 June 2018

\section{(c) EY-No}

LICENSE

This work is licensed under a Creative Commons Attribution-NonCommercial 4.0 International License

JOURNAL " "Environmental Economics"

ISSN PRINT

$1998-6041$

ISSN ONLINE

1998-605X

PUBLISHER

LLC "Consulting Publishing Company "Business Perspectives"

FOUNDER

LLC "Consulting Publishing Company "Business Perspectives"

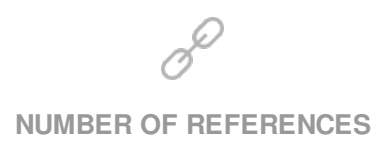

65

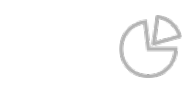

NUMBER OF FIGURES

1
ニ:-

NUMBER OF TABLES

8

(C) The author(s) 2023. This publication is an open access article. 
Fatai Abiola Sowunmi (Nigeria), Adewumi Oyewunmi Oyebanjo (Nigeria), Osarobo Cecil Omigie (Nigeria), Zakariyah Olayiwola Amoo (Nigeria)

\title{
Demand for charcoal among petty traders in Oyo state, Nigeria: a paradox of survival and environmental degradation
}

\begin{abstract}
Striking a balance between human survival heightened by mass unemployment and the environment is crucial to the sustainability of the natural resources. The role of petty trader is important in ensuring that the excess supply during harvest is processed into the forms (roasted maize, yam, plantain, meat and chicken) appreciated by consumers instead of being a loss to farmer. While average daily income of 2670.79 Nigerian naira (N) was assured, substantial quantity of charcoal (46786.3 $\mathrm{kg}$ ) was utilized per week by petty traders. This is equivalent of 20.6 hectares of wood. The per capita charcoal utilization per week for suya, roasted yam and plantain sellers were $178.7 \mathrm{~kg}, 85.2 \mathrm{~kg}$ and $145.8 \mathrm{~kg}$, respectively. These were obtained from clearing 0.8 ha (suya), 0.4 ha (roasted yam) and 0.6 ha (plantain) of wood. Age of respondents, experience in petty trading and hours of trading per day have a positive influence on the quantity of charcoal utilized per day, while frequency of purchase (charcoal) and rainy season have a negative relationship with quantity of charcoal used per day. Considering the appreciable quantity of charcoal utilization among petty traders and its negative effect on the environment, government should go beyond collecting taxes from charcoal producers. Also, the need for control over exploitation of trees and mobilization of staff of the Ministry of Forestry for prompt tree planting are required.
\end{abstract}

Keywords: charcoal, petty trader, deforestation, farm production, environment.

JEL Classification: Q21, Q23, Q56.

Received on: $9^{\text {th }}$ of March, 2018.

Accepted on: 20 ${ }^{\text {th }}$ of June, 2018.

\section{Introduction}

Small scale business occupies a unique position in the economy of any nation. It constitutes the cornerstone of any competitive economy and by far outnumbers the large-scale business. As a result of easy entry into the market, small-scale business springs up all the time keeping the competition environment lively, a phenomenon that leads to productivity gains and real economic growth, Small scale business is closer to the grass root and it gingers rural development. They are less capital intensive and do not require gigantic infrastructure for their operation (Hiproject, 2017). Small business is crucial for economic growth, poverty alleviation and wealth creation (Capenter, 2001). Petty trading falls into this category of economic activities. According to Mbisso (2012), petty trading can be referred to as an economic activity that involves selling (and buying) goods and services in small scale, ranging from agricultural produce to locally

\footnotetext{
(C) Fatai Abiola Sowunmi, Adewumi Oyewunmi Oyebanjo, Osarobo Cecil Omigie, Zakariyah Olayiwola Amoo, 2018.

Fatai Abiola Sowunmi, Ph.D., Lecturer, Department of Agricultural Economics, University of Ibadan, Ibadan, Oyo State, Nigeria.

Adewumi Oyewunmi Oyebanjo, Student, Department of Agricultural Economics, University of Ibadan, Ibadan, Oyo State, Nigeria.

Osarobo Cecil Omigie, Ph.D., University of Ibadan, Ibadan, Oyo State, Nigeria.

Zakariyah Olayiwola Amoo, Ph.D, Lecturer, Department of Agriculture, Lagos State University, Epe, Lagos, Nigeria.

This is an Open Access article, distributed under the terms of the Creative Commons Attribution-NonCommercial 4.0 International license, which permits re-use, distribution, and reproduction, provided the materials aren't used for commercial purposes and the original work is properly cited.
}

produced and imported consumer goods. Petty trading constitutes a collection of individual sellers with small capital and buyers operating in a group of small spaces. It is a prevailing socioeconomic activity serving a multitude of the low-income population in rapidly developing countries (United Nation Habitat, 2009). Most people involved in petty trading do their business transactions in stalls, open space, road side and sometimes in make shift stores (Anyamba, 2006). The capital required to set up such business is meagre as low as $\$ 2000$ equivalent of $\$ 5.6$ at the current exchange rate of $\$ 1$ to $\$ 356$. It is an integral part of informal sector of the economy, which is usually not recognized, regulated, or protected by legal or regulatory frameworks (Amin, 2002; ILO, 2002, 2003). The informal sector accounted for 57.9 percent of Gross Domestic Product (GDP). Also, the informal sector contributes 80 percent of the labor force in Africa (UNDP, 2014; Datamania Consult, 2014).

Retail trading has increasingly received attention as one of the most important activities in urban development processes. The Enterprise Baseline Survey report (2012) revealed that there are 17 million small and medium scale enterprises in Nigeria, employing 32.4 million persons and contributes of about 46.5 percent to the Nigerian GDP (Elebeke, 2012). Trading in the processing of agricultural produce such as roasted plantain, maize, yam and meat (suya) in markets and along the major roads of urban and rural areas is a very common small-scale enterprise in Nigeria. However, as a 
result of the seasonality of agricultural products, petty traders often change the products they sell from time to time for continuity in business. Petty trading is basically a major source of employment (approximately 60 per cent of urban jobs) and income to poor and low-income households. With high level of unemployment attributed to infrastructural decay, the role of petty trading in providing jobs for the low-income members of the population estimated to be 182.2 million in 2015 (National Population Commission, 2016) cannot be overemphasized. With the economic recession, the unemployment rate stood at $14.2 \%$ as at the fourth quarter of 2016 (using NBS new methodology). This means that 28.58 million persons were unemployed.

Baring the myriads of basic problem facing agriculture, it has, the potential to employ 70 percent of the country's labor force. However, the problem of storage and perishability of food crops are peculiar across the six agro-ecological zones of Nigeria; most especially, the seasonal food crops (maize, yam and plantain) whose supply usually exceeds the demand during harvest. Nigeria loses over 60 percent of farm produce annually due to lack of storage and agro-processing facilities (Oketola, 2016).

The petty trading play a significant role in taking up the excess supply and process them in different forms (such as roasted plantain, maize, yam and meat) acceptable to consumers using charcoal as the source of energy. These are local snacks consumed by Nigerians: regardless of income status. Charcoal produces little or no flame; it is portable and has better energy efficiency; charcoal contains double energy of ordinary firewood and burns faster; it adds flavor, color and texture to food (Waters, 2015; Eweoya, 2006; Ajao, 2011). Global, charcoal production increased by $3.7 \%$ annually in 1990 to reach 44 million tons in 2000 (FAO, 2008). The extraction of trees for wood fuels equals almost 61 percent of total wood removal globally, while 90 percent of wood harvested in Africa is used as firewood and charcoal for cooking, as hundreds of millions of people, including petty traders, remain completely dependent upon wood for fuels, especially charcoal (FAO, 2005). The daily activities of petty traders involve the use of charcoal, which is obtained through deforestation with consequent land degradation and soil erosion. The flexibility of petty trading under study makes it possible to trade all-year-round by dealing in any of the seasonal agricultural products (maize, yam and plantain) available. The high demand for charcoal might have contributed to Nigeria being the second leading producer of charcoal (8\%) in the world after Brazil (Worldatlas, 2018). Ajao (2011) affirmed that thousands of bags of charcoal enter most of urban centres on a daily basis for household and petty trader uses. These add up to large tonnage of charcoal utilized annually, for which trees had to be cut from forest which is of no interest to petty trader. From the foregoing, substantial quantity of charcoal would be used yearly.

However, previous studies (Adedeji \& Aiyeloja, 2014; Anang et al., 2011; Jelili et al., 2015; Eweoya, 2006; Ajao, 2011; Kunnibe et al., 2013; Adepoju et al., 2012; Onoja \& Idoko, 2012; Nyembe, 2011) concentrated on charcoal production and efficiency of charcoal production. Also studies on the demand for charcoal only considered household utilization. The belief that the charcoal utilization by petty trader is in significant might have contributed to the dearth of research on demand for charcoal among petty traders that this study setout to address. The study did not only determine the average quantity of charcoal $(\mathrm{kg})$ used per day by petty traders to process agricultural produce, but also estimated the equivalent quantity of wood required to produce the charcoal used in the study area. The study identified factors influencing charcoal utilization per day in the study area.

\section{Theoretical framework and literature review}

The theory of land degradation states that annihilation of forested areas, wetlands, grasslands, etc. arises because of the difference between the discount rate of the individual and the society as a whole (Meyeres, 1985).

The demand for woodfuel (charcoal) like other economic goods among petty traders has a negative relationship with the price. However, as the price increases, the cost implication is born by the final consumer of the products (examples are roasted plantain, yam and corn) who are expected to pay more for the same product. This depends on the status (necessity or luxury) of the finished product to the final consumer. The cost of woodfuel (charcoal) is primarily determined by the following factors: time, labor, capital and technological advances (Samuelson \& Nordhaus, 2005). Among the petty traders engaged in roasting yam, maize, plantain and suya by the road side, there is no substitute to charcoal as source of energy for their business. Hence, availability of substitute is not a factor influencing the demand for charcoal. The existing literature on charcoal is on production, 
production efficiency and household utilization (Adedeji \& Aiyeloja, 2014; Anang et al., 2011; Jelili et al., 2015; Eweoya, 2006; Ajao, 2011; Kunnibe et al., 2013; Adepoju et al., 2012; Onoja \& Idoko, 2012; Nyembe, 2011). Sufficient interests have not been shown by researchers to studies on charcoal utilization by petty traders who roast yam, maize, plantain and soya by roadsides of urban and rural areas in most parts of Nigeria. While descriptive analysis was commonly used in charcoal production studies, other different analytical tools have been used on household utilization of charcoal. These included LA-AIDS, logistic regression, tobit regression, two-stage least square and probit regression. However, restrictions of LA-AIDS model reveal simultaneity bias problem. While Adepoju et al. (2012) revealed that as per capita income increases, expenditures on charcoal increases. Also, Nyembe (2011) found that as per capita expenditure of household increases, the probability of using charcoal as source of energy at home increases at a decreasing rate. Studies (Nymbe, 2011; Ajao, 2011; Kunnibe et al., 2013) affirmed that the higher the education a household head possesses, the lower the probability of consuming charcoal would be. Babanyara and Saleh (2010) posited that rural-urban migration, poverty and hikes in price of kerosene were critical factors influencing demand for woodfuel (charcoal and firewood) in urban Nigeria.

Demand for woodfuel (charcoal or firewood) in the rural areas of developing countries is usually higher than in urban areas. One of the main reasons for this is inability of the households to have access to other fuels, such as gas and fossil fuels in the energy mix of the urban areas (Egeru, 2014; FAO, 1993; Brouwer \& Falcão, 2004; Luoga et al., 2000a).

The bulk of charcoal wood is clear-cut from secondary and, in some cases, primary forest (Brandley, 1991). Emissions during charcoal production are significant and contribute heavily to global climate change impact. The charcoal oven emission ratios of $\mathrm{CO}, \mathrm{CH} 4, \mathrm{NMHC}$, and $\mathrm{NH} 3$ to $\mathrm{CO} 2$ are larger with much higher global warming potential. Apart from exposing the soil to agent of denudation, Adedeji and Ayeloja (2014) posited that charcoal production impacts negatively on the survival of the honeybees' colonies and population.

Jelili et al. (2015) found that large percentage of the wood used in the production of charcoal is obtained from trees deliberately felled for the purpose of charcoal production. Only a few proportions of such woods are obtained from trees that die naturally.
This revealed high rate of deforestation tendency without any effort towards afforestation.

Charcoal production efficiency varies between 10\% and 25\% (Awodele et al., 2014; Lew \& Kammen, 1997; Okello et al., 2001; Stassen, 2002, Pereira \& Joaquim, 2001; Falcão, 2005).

\section{Methods}

The study was carried out in Oyo state, Nigeria. Five of the major towns in Oyo state known for petty trading (roasting of yam, maize, soya and plantain) were considered for the study. These are Ogbomosho, Oyo, Iseyin, Eruwa and Ibadan; the capital of Oyo state. These towns are known for farming in arable crops (yam, maize and plantain), which serve as raw material for further processing by petty traders into the forms acceptable by consumers. According to NPC (2006), Oyo state has a population of 5,580,894 with Ibadan metropolis alone having $73.9 \%$ of the total population $(2,550,593)$. The towns/cities are major centres for trade in agricultural and non-agricultural products. With high unemployment rate in Nigeria (21.1\%), $15 \%$ in Southwest Nigeria and $8.8 \%$ in Oyo state (NBS, 2010), petty trading is seen as a temporary way of earning means of livelihood among the populace in major cities in Nigeria dealing with different commodities, including roasting of seasonal agricultural food crops, such as maize, yam, plantain and suya (grilled meat) by the roadside.

Multi-stage sampling was used to select respondents in the study area. Five subtowns with substantial population and historical links to petty trading in processed agricultural products were purposively selected from the list of towns in Oyo state. The selected subtowns were thirty three (33) in Ogbomosho, the subtowns were Apake, Oluode layout, Oremerin, Oke Ado and Sabo motor park; in Oyo, the subtowns were Agunpopo, Araromi, Ilaka, Isale Oyo, Lagbondoko, Oke Apo, Oke-Ebo, Oranmiyan and Owode, Ibadan Metropolis, the subtowns were Bodija, Sango, Mokola, Sabo, Dugbe, Ojo, Beere, Oje, Molete and Idi-Arere, while Abugaga, Adewuyi, Ajagbadi, Ajofin, Ado Awaye, Aba Tapa, Aboriso and Osugun were considered in Iseyin and Eruwa. Twenty (20) respondents were randomly selected from each of the towns in Ibadan Metropolis giving a total of 200 respondents, while 10 respondents were selected from other subtowns outside Ibadan Metropolis (230). The disparity in the number of respondents was as a result of large population of Ibadan Metropolis, which encouraged large number of petty traders (roasting of maize, yam, 
plantain and beef). Data were collected using structured questionnaire. The choice of questionnaire was because it ensures uniformity of data from respondents. Data were collected on the socioeconomic characteristics of respondents (age, household size, educational status), daily sales, daily expenditure on charcoal, frequency of charcoal purchased per week, the agricultural produce the traders deal with, years of experience in the trade, among others. Out of 430 questionnaires administered, 385 were good enough for analysis.

Data were analyzed using descriptive statistics to profile the socioeconomic characteristics of the petty traders, as well as to obtain the equivalent of hectares of wood to the charcoal utilized for roasting yam, plantain, maize and suya by petty traders in the study area. The average charcoals utilized among different groups of petty traders were compared using ANOVA (Analysis of Variance), while multiple regression analysis was used to determine the factors influencing the quantity $(\mathrm{kg})$ of charcoal used per day by petty traders in the study area. The expected summary of the ANOVA is shown in Table 1.

Table 1. The one-way ANOVA table

\begin{tabular}{|l|c|c|c|c|}
\hline \multicolumn{1}{|c|}{ Source of variation } & Sum of squares & Degree of freedom & Mean squares & F-ratio \\
\hline $\begin{array}{l}\text { Between groups (roasted } \\
\text { yam, maize, plantain and } \\
\text { suya sellers) }\end{array}$ & $S S B=\sum_{j=1}^{k} n_{j}\left(\bar{X}_{j}-\bar{X}_{t}\right)^{2}$ & $k-1$ & $M S B=\frac{S S B}{(k-1)}$ & \\
\hline $\begin{array}{l}\text { Within groups (roasted } \\
\text { yam, maize, plantain and } \\
\text { suya sellers) }\end{array}$ & $S S W=\sum_{j=1}^{k} \sum_{i=1}^{n}\left(X_{i j}-\bar{X}_{j}\right)^{2}$ & $n-k$ & $M S W=\frac{S S W}{(n-k)}$ & \begin{tabular}{c}
$\frac{S S B}{(k-1)}$ \\
\hline Total
\end{tabular} \\
\hline
\end{tabular}

where:

- SSB represents sum of squares between groups (yam roasters, plantain roasters, maize roasters and suya roasters);

- SSW represents sum of squares within groups (yam roasters, plantain roasters, maize roasters and suya roasters);

- SSE represents sum of squares within groups;

- SST represents sum of squares for total;

- MSEB represents mean square error between groups;

- MSEW represents mean square error within groups;

- $n$ represents sample size;

- $k$ represents number of categories.

The model for the multiple regression model is represented by:

QUNTCHA $=\beta 0+\beta 1 \mathrm{AGE}+\beta 2 \mathrm{GNDR}+$ $\beta 4 \mathrm{MARST}+\beta 5 \mathrm{HHS}+\beta 6 \mathrm{TEXP}$

$+\beta 7$ FREQP + B8RAISEA $+\beta$ 9DRYSEA + $\beta 10$ TRAHR $+\beta 11$ SALRE $+\varepsilon i$ where:

- QUNTCHA represents quantity $(\mathrm{kg})$ of charcoal used by the respondents per day;

- AGE represents age (years) of respondents;

- GNDR represents gender of the respondents;

- MARST represents marital status of the respondents;

- HHS represents household size of the respondents;

- TEXP represents years of trading experience (year);

- FREQP represents frequency of purchasing charcoal per week;

- RAISEA represents rainy season (Yes $=1$, No $=$ 0 );

- DRYSEA represents rainy season (Yes $=1$, No $=0$ );

- TRAHR represents average trading hours per day;

- SALRE represents daily sales income $(\mathrm{N})$ of respondents;

- $\quad$ i i represents error term. 


\section{Results and discussion}

3.1. Socioeconomic characteristics of respondents. Figure 1 shows that majority (29.4\%) of the respondents were within the age bracket of $31-40$ years, while only $9.4 \%$ and $1.9 \%$ were between 61-70 and 71-80 years, respectively. The average age of respondents was 42.1 years, while the skewness was positive (0.49) indicating that majority of the respondents were below 42.1 years (average age). The disaggregation of the results showed that the average ages of the petty traders dealing in roasted yam, roasted plantain and maize were $34.2,46.3$ and 36.3 years, respectively. This shows that those engaging in petty trading were in their economic active ages. Table 2 shows that petty traders involved in roasting of agricultural products (yam, maize, plantain and meat) were dominated by married females $(75.6 \%)$, with the exception of suya, which is dominated by male (24.4\%). Specifically, the study showed that the average household size was approximately 6.0 (5.9), with most respondents having household size of less than 6 . Furthermore, the study revealed that most of the respondents $(30.6 \%)$ had been in petty trading business between 6-10 years with an average year of trading experience of 12 years. The flexibility of this business allowed traders to change from one agricultural produce to the other depending on the season, which might have contributed to the long span of operation. Almost all the respondents $(97.5 \%)$ used charcoal to process agricultural produce into eatable form, while other respondents used electricity (microwave) and gas as sources of energy to complement the use of charcoal for grilling beef, chicken and fish only. The breakdown of the petty traders based on the trading agricultural produce revealed that most respondents $(20.3 \%)$ were dealing in roasted suya, while $16.3 \%, 14.4 \%$ and $16.3 \%$ were trading in roasted maize, yam and plantain, respectively (see Table 6).

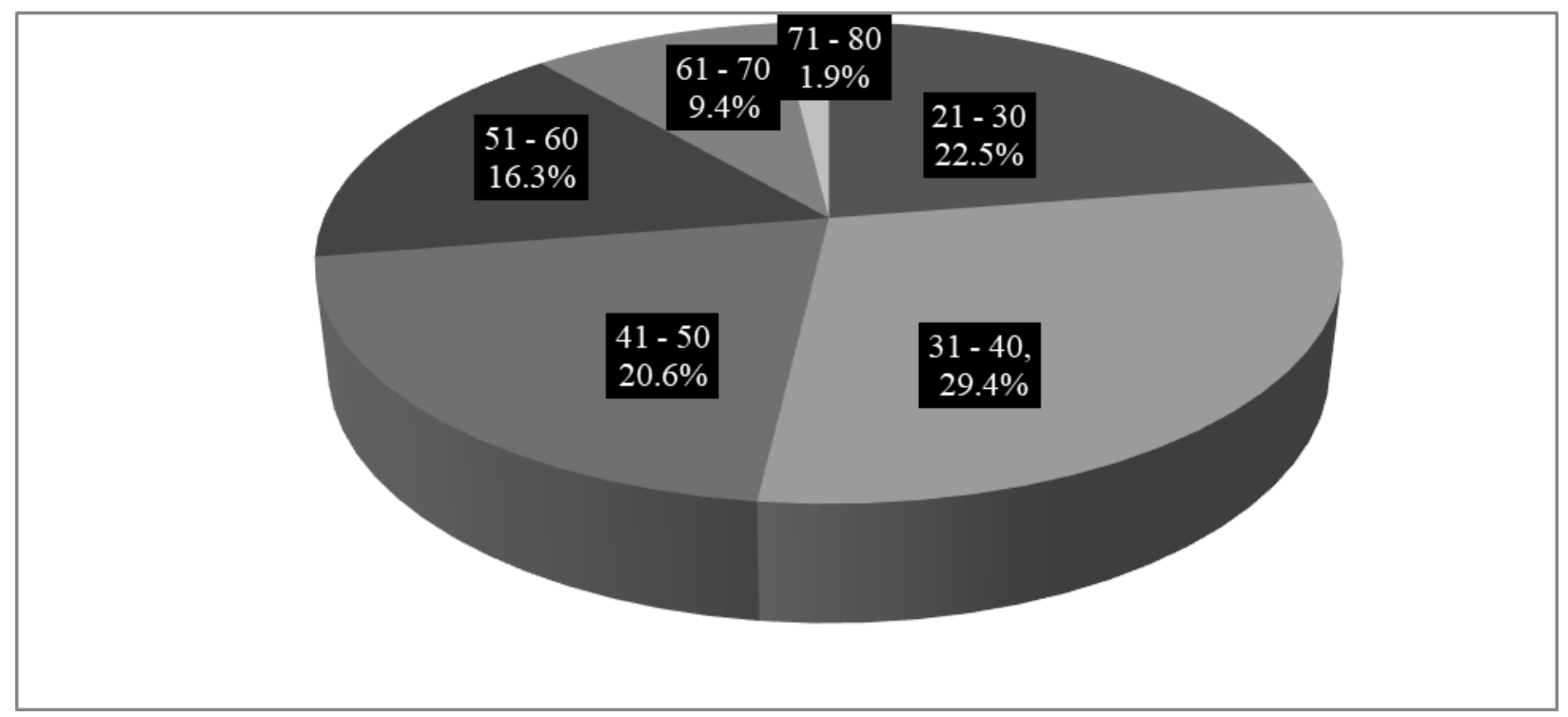

Source: Field survey (2016).

Fig. 1. Age distribution of respondents

Table 2 shows that $31.3 \%$ of the respondents had no formal education, while $65.1 \%$ had at most primary education. Only $29.4 \%$ of the respondents had secondary school education. The distribution shows that petty trading in processed farm produce was common among populace with low level of education.

Table 2. Socioeconomic characteristics of respondents

\begin{tabular}{|l|c|c|}
\hline \multicolumn{1}{|c|}{ Variable } & Frequency & Percentage \\
\hline Gender & & 24.4 \\
\hline Male & 94 & 75.6 \\
\hline Female & 291 & \\
\hline Marital status & & 1.3 \\
\hline Single & 5 & 89.4 \\
\hline Married & 344 & 9.4 \\
\hline Widowed & 36 & \\
\hline Household size & & 21.4 \\
\hline $1-3$ & 82 & \\
\hline
\end{tabular}


Table 2. (cont.) Socioeconomic characteristics of respondents

\begin{tabular}{|l|c|c|}
\hline $4-6$ & 154 & 40.0 \\
\hline $7-9$ & 119 & 31.0 \\
\hline 10 and above & 29 & 7.6 \\
\hline Educational status & & 31.3 \\
\hline No formal education & 121 & 33.8 \\
\hline Primary education & 130 & 29.4 \\
\hline Secondary education & 113 & 1.9 \\
\hline Ordinary national diploma/ National certificate in education & 7 & 1.3 \\
\hline Higher national diploma & 5 & 1.3 \\
\hline B.Sc & 5 & \\
\hline Years of trading experience & & 25.0 \\
\hline $1-5$ & 96 & 30.6 \\
\hline $6-10$ & 118 & 11.9 \\
\hline $11-15$ & 46 & 18.8 \\
\hline $16-20$ & 72 & 7.5 \\
\hline $21-25$ & 29 & 3.1 \\
\hline $26-30$ & 12 & 3.1 \\
\hline 31 and above & 12 & \\
\hline
\end{tabular}

Source: Field survey (2016).

3.2. Respondents' expenditure and returns on charcoal utilization. The average frequency of charcoal purchase per week by the traders was $4.8(\approx 5$ times). The negative skewness $(-0.65)$ indicates that most of the traders bought charcoal more than 5 times in a week. The result showed an average expenditure of 1882.05 per week ( $\$ 376.41$ per day) per trader on charcoal. Also from the result, most of the traders spent less than $\$ 376.41$ per day on charcoal (positive skewness). Table 3 shows that the value attached to the food determines the individual daily sales revenue regardless of the amount incurred on charcoal.

Table 3. Average quantity $(\mathrm{kg})$ of charcoal utilized, expenditure on charcoal and sales revenue of traders per day

\begin{tabular}{|l|c|c|c|}
\hline \multicolumn{1}{|c|}{ Produce } & Quantity (kg) of charcoal & Average expenditure on charcoal (\#) & Average sales (\#) \\
\hline Yam & 21.48 & 273.91 & 1946.13 \\
\hline Maize & 21.81 & 272.12 & 2272.22 \\
\hline Suya & 42.44 & 504.69 & 5529.54 \\
\hline Plantain & 35.88 & 444.23 & 2328.52 \\
\hline Maize and plantain & 23.13 & 280.43 & 2573.08 \\
\hline
\end{tabular}

Source: Field survey (2016).

Daily sales revenue, quantity and expenditure on charcoal for suya (roasted meat or chicken) were the highest. Sales of suya is not seasonal unlike other produce that were sold at specific months of the year. The table shows that the suya sellers had the highest average daily sales; this was followed by combination of maize and plantain. Table 4 shows that $82.5 \%$ of the respondents earned at most $\$ 4000$ per day, while $4.4 \%$ earned between $\$ 8001$ and $\$ 12000$. Only $0.6 \%$ of the respondents recorded 16001- 20000. Almost all the respondents who earned at least $\$ 8000$ per day were suya sellers. An average daily sale was 2670.79, while most respondents earned less than the average daily sales (positive skewness). With the average household size of 5.9, the average per capita daily income of petty trader in the study area was 452.68. This is far below the national average per capita income per day of $\$ 2867.43$ (https://tradingeconomics.com/nigeria/gdp-per-capita), an indication of poverty among the petty traders in the study area. 
Table 4. Distribution of daily sales ( $)$ among respondents

\begin{tabular}{|c|c|c|}
\hline Sales income $(\mathrm{N})$ & Number of respondents & Percentage \\
\hline $0-4000$ & 318 & 82.5 \\
\hline $4001-8000$ & 41 & 10.6 \\
\hline $8001-12000$ & 17 & 4.4 \\
\hline $12001-16000$ & 7 & 1.9 \\
\hline $16001-20000$ & 2 & 0.6 \\
\hline
\end{tabular}

\section{Equivalent hectares of wood to the charcoal utilized per day}

Table 5 shows the per capita charcoal utilization per week by the different groups of petty traders (roasted yam sellers, roasted maize sellers, suya sellers, roasted plantain sellers and roasted maize and plantain sellers) in the study area. The breakdown shows that on average, suya sellers have the highest per capita charcoal utilization of 178.7 $\mathrm{kg}$. This was followed by plantain, maize and plantain, maize and yam. The equivalent quantity of wood to charcoal utilized was computed using $1 \mathrm{~kg}$ of charcoal equal to $10 \mathrm{~kg}$ (Stassen, 2002; Habermehl, 2007; GIZ HERA, 2016). This was based on traditional method of charcoal production adopted by major production areas in Southwest Nigeria (Imeko/Afon local government area of Ogun state and Iwajowa local government area of Oyo state). This has implication on the size of forest area, cleared in order to produce the required quantity of charcoal.

Table 5. Per capita charcoal utilization per week by the different categories of traders

\begin{tabular}{|l|c|c|c|c|c|}
\hline Groups of petty traders & $\begin{array}{c}\text { Number of respondents } \\
\text { trading in each produce }\end{array}$ & $\begin{array}{c}\text { Total quantity of } \\
\text { charcoal utilized }(\mathrm{kg}) \\
\text { per week }\end{array}$ & $\begin{array}{c}\text { Per capita charcoal } \\
\text { utilization (kg) per week }\end{array}$ & $\begin{array}{c}\text { Equivalent quantity of } \\
\text { wood (kg) from charcoal } \\
\text { per week }\end{array}$ & $\begin{array}{c}\text { Ranking based on } \\
\text { per capita charcoal } \\
\text { utilization }\end{array}$ \\
\hline Yam & 70 & 5962.1 & 85.2 & 852 & $5^{\text {th }}$ \\
\hline Maize & 77 & 6918.0 & 89.8 & 898 & $4^{\text {th }}$ \\
\hline Suya & 91 & 16260.3 & 178.7 & 1787 & $1^{\text {st }}$ \\
\hline Plantain & 77 & 11225.2 & 145.8 & 1458 & $2^{\text {nd }}$ \\
\hline Maize and plantain & 70 & 6420.7 & 91.7 & 917 & $3^{\text {rd }}$ \\
\hline Total & 385 & 46786.3 & 121.5 & 1215 & \\
\hline
\end{tabular}

Source: Field survey (2016).

Moreover, the equivalent quantity of wood cleared in the forest to produce the per capita charcoal utilization of each trader is calculated based on 25 tons of wood per ha (FAO, n.d.; Pari, 2000). The 25 tons of wood per hectare are equivalent to 22727.27 $\mathrm{kg}$ of wood per hectare. This implies that the suya sellers consumed approximately 7.2 hectares of wood per week, roasted yam sellers consumed 2.6 hectares of wood per week, while roasted plantain sellers utilized 4.9 hectares of wood per week in the course of their business. Moreover, all the respondents (petty traders) consumed 20.6 hectares of wood per week. Sedano et al. (2016) posited that fuel wood collection is mainly consumed in rural areas; charcoal production is driven by urban demand for petty trading and household uses. Both the producers of charcoal and the petty traders are less concerned on the destruction of the forest as long as they are earning money. Once the trees are exhausted in one part of a forest, they move to the other parts with enough trees without replacement for the cut trees.

Table 6. Distribution of respondents by the choice of the roasted foods being sold

\begin{tabular}{|l|c|c|}
\hline \multicolumn{1}{|c|}{ Food } & Frequency & Percentage \\
\hline Yam & 55 & 14.4 \\
\hline Yam, maize & 2 & 0.6 \\
\hline Goat meat & 2 & 0.6 \\
\hline Maize & 63 & 16.3 \\
\hline Suya & 77 & 20.0 \\
\hline Plantain & 63 & 16.3 \\
\hline Maize, plantain & 55 & 14.4 \\
\hline
\end{tabular}


Table 6. (cont.) Distribution of respondents by the choice of the roasted foods being sold

\begin{tabular}{|l|c|c|}
\hline \multicolumn{1}{|c|}{ Food } & Frequency & Percentage \\
\hline Yam, maize, plantain & 24 & 6.3 \\
\hline Chicken & 10 & 2.5 \\
\hline Yam, plantain & 31 & 8.1 \\
\hline Maize, plantain, groundnut & 2 & 0.6 \\
\hline Total & 385 & 100 \\
\hline
\end{tabular}

Source: Field survey (2016).

Furthermore, the result of Analysis of Variance (see Table 7) shows that there was significant variation in the average daily expenditure on charcoal among the petty traders selling various processed farm produce $(\mathrm{p}<0.05)$. This is expected bearing in mind different time frame required to process each of the produce to the form acceptable to consumers. Also, the trading hour per day differs from one petty trader roasting one farm produce to the other. While traders selling roasted yam, plantain and maize mostly restricted their trading hours to day time, suya sellers targeted evening and night.

Table 7. Analysis of Variance result for comparing daily expenditure on charcoal by petty traders

\begin{tabular}{|l|c|c|c|c|c|c|}
\hline \multicolumn{1}{|c|}{ Source of variation } & SS & Df & MS & F & P-value & F crit \\
\hline Between groups & 1367198 & 4 & 341799.5 & 4.10 & 0.004 & 2.44 \\
\hline Within groups & 22911644.3 & 275 & 83315.07 & & & \\
\hline Total & 24278842.3 & 279 & & & & \\
\hline
\end{tabular}

Source: Field survey (2016).

\section{Factors influencing average quantity of charcoal used by petty traders per day}

Table 8 shows the result of multiple regression analysis for determining the factors influencing the quantity of charcoal used per day in the study area. The diagnostic result showed that $66.4 \%\left(\mathrm{R}^{2}\right.$ $=0.6643)$ of the variation in the quantity of charcoal utilized per day in the study area was attributed to the independent variables (age of respondents, experience in petty trading, frequency of purchase, season and hours of trading). The reported F-value (12.78) shows that there was overall significance of the model $(p<0.05)$. The significant coefficients were age $(p<0.10)$, experience in petty trading $(p<0.01)$, frequency of purchase $(p<0.05)$, and hours of trading $(p<0.01)$ were significant. Coefficients of age, experience in petty trading, dry season and hours of trading had positive relationship with the quantity of charcoal utilized per day in the study area. Conversely, frequency of purchase (charcoal) and rainy season had negative relationship with quantity of charcoal utilized per day. Specifically, the result shows that as trader gets older, the quantity of charcoal used per day increases. This may be attributed to commitment to the family needs among older petty traders. The disruption of trading activities during the rainy season may be attributed to the negative relationship with quantity of charcoal used. The level of disruption depends on the duration of rainfall, as well as the intensity. Petty traders are generally affected by rain since their trading is done in the open, close to the main road. Also, the result showed that the longer trading hour associated with dry season brought about increased in the quantity of charcoal used by petty trader. Generally, traders roasting plantain, yam and maize stayed longer than the suya sellers that trade in the evening. The average trading hour for roasted plantain, maize and yam sellers was 8.7 hours (mostly from 10:00 am - 7:00 pm), while suya sellers' average trading hour was 4.4 hours (mostly from 7:00 pm-11:30 pm).

Table 8. Result of multiple regression analysis

\begin{tabular}{|l|c|c|c|c|}
\hline \multicolumn{1}{|c|}{ Independent variables } & Coefficient & Standard error & t-value & P-value \\
\hline AGE & $0.403^{*}$ & 0.216 & 1.87 & 0.064 \\
\hline GNDR & 5.020 & 7.195 & 0.70 & 0.487 \\
\hline EDUC & -3.361 & 4.556 & -0.74 & 0.459 \\
\hline MARST & 6.885 & 12.890 & 0.53 & 0.594 \\
\hline TEXP & $0.589^{\star \star *}$ & 0.213 & 2.77 & 0.007 \\
\hline HHS & -1.618 & 2.727 & -0.59 & 0.555 \\
\hline FREQP & $-2.292^{* *}$ & 1.157 & -1.98 & 0.048 \\
\hline
\end{tabular}


Table 8.(cont.) Result of multiple regression analysis

\begin{tabular}{|l|c|c|c|c|}
\hline \multicolumn{1}{|c|}{ Independent variables } & Coefficient & Standard error & t-value & P-value \\
\hline RAISEA & $-1.452^{* * *}$ & 0.553 & -2.63 & 0.009 \\
\hline DRYSEA & $2.478^{* *}$ & 1.305 & 2.06 & 0.039 \\
\hline TRAHR & $4.334^{* * *}$ & 1.229 & 3.53 & 0.000 \\
\hline SALRE & 0.0017 & 0.0012 & 1.49 & 0.137 \\
\hline${ }_{\text {CCons }}$ & $42.974^{* * *}$ & 13.513 & 3.18 & 0.002 \\
\hline
\end{tabular}

$\mathrm{F}(7.137)=12.78, \mathrm{p}$-value $=0.0000$

$\mathrm{R}^{-2}=0.6642$

*** Significant at 1\%,** Significant at 5\%, Significant at $10 \%$.

Source: Field survey (2016).

\section{Conclusion}

The study examined the demand for charcoal among petty traders (roasted yam, maize, plantain and meat/chicken) in Ibadan Metropolis. The study revealed that petty trading was dominated by female (75.6\%) and common among the populace that are not well educated $(65.1 \%$ had at most primary school leaving certificate) with most respondents within the age bracket of 41-50 years. Expenditure on charcoal per day was the highest among the suya sellers, while average expenditure on charcoal per day was 376.41 among the respondents. There was a significant difference in the average daily expenditure on charcoal. The average daily income and per capita daily income were $\$ 2670.79$ and 452.68, respectively. The study affirmed that substantial quantity of charcoal $(19,460 \mathrm{~kg})$ was utilized per week by respondents in the study area. This is equivalent of 0.86 hectares of wood. The per capita charcoal utilization per week for suya, roasted yam and plantain sellers were $178.7 \mathrm{~kg}, 85.2 \mathrm{~kg}$ and $145.8 \mathrm{~kg}$, respectively. These were obtained from clearing 0.7 ha (suya), 0.4 ha (roasted yam) and 0.6 ha (plantain) of wood. Age of respondents, experience in petty trading and hours of trading per day have a positive influence on the quantity of charcoal utilized per day, while frequency of purchase (charcoal) and rainy season have a negative relationship with quantity of charcoal used per day in the study area.

The substantial quantity of charcoal used by the petty trader as revealed by the study has strong implications on deforestation. However, this can be reduced with improved economy, which may draw out some participants to other economic activities other than roasting farm produce. However, in order to reduce the negative effects of demand for charcoal, which promotes deforestation (although some scholars disagree: Arnold and Persson (2003); May-Tobin (2011), government should go beyond collecting taxes from charcoal producers. The need for control over exploitation of trees and mobilization of staff of the Ministry of Forestry for prompt tree planting, where intensive deforestation has taken place, is imperative.

\section{References}

1. Adam, J. C. (2009). Improved and more environmentally friendly charcoal production system using a low-cost retort-kiln (Eco-charcoal). Renew Energy, 34, 1923-1925.

2. Adedeji, G. A., \& Aiyeloja, A. A. (2014). Effect of Commercial Charcoal Production on the Availability of Wood Cavity and Survival of Genetic Honeybee's Resource in Imeko, Nigeria. Nat Sci., 12(12), 123-132. Retrieved from http://www.sciencepub.net/nature. 18

3. Adepoju, A. O., Oyekale, A. S., \& Aromolaran, O. (2012). Rural Households' Demand for Domestic Energy in Odeda Local Government Area (LGA) of Ogun State, Nigeria. J. Hum Ecol, 40(2), 115-123.

4. Ajao, A. O. (2011). Determinants of Urban Charcoal Demand in Ogbomoso Metropolis. World Rural Observations, 3(4), 90-97.

5. Akagi, S. K., Yokelson, R. J., Wiedinmyer, C., Alvarado, M. J., Reid, J. S., \& Karl, T. (2010). Emission factors for open and domestic biomass burning for use in atmospheric models. Atmos Chem Phys Discuss, 10, 27523-27602.

6. Amin, N. (2002). The Informal Sector in Asia from Decent Work Perspective (Working Paper 2002/4). Geneva, ILO.

7. Anang, B. T., Akuriba, M. A., \& Alerigesane, A. A. (2011). Charcoal production in Gushegu District, Northern Region, Ghana: Lessons for sustainable forest management. International Journal of Environmental Sciences, 1(7), 1944-1953.

8. Anyamba, T. (2006). Diverse Informalities: Spatial Transformations in Nairobi. A study of Nairobi's Urban Process. Oslo: Oslo School of Architecture.

9. Arnold, M., \& Persson, R. (2003). Reassessing the fuelwood situation in developing countries. Int For Rev., 5, 379-383. 
10. Awodele, D. O., Famuyide, O., Bolaji-Olatunji, K. A. \& Adeniran, O. A. S. (2014). Determinants of Charcoal Production Efficiency in Ibarapa North Local Government of Oyo State, Nigeria. Journal of Agriculture, Forestry and the Social Sciences, 11,(1)34-54.

11. Babanyara, Y. Y., \& Saleh, U. F. (2010). Urbanisation and the Choice of Fuel Wood as a Source of Energy In Nigeria. J Hum Ecol, 31(1), 19-26.

12. Brandley, P. N. (1991). Women, Wood fuel and Woodlots. McMillan Ltd. London.

13. Brouwer, R, \& Falcão, M. P. (2004). Wood fuel consumption in Maputo, Mozambique. Journal of Biomass and Bioenergy, 27(3), 233-245.

14. Carpenter, R. B. (2001). The Freedom Revolution. Washington, D.C: Regnrey Publishing Co.

15. CHAPOSA (2002). Charcoal potential in Southern Africa. INCO_DEV: International Cooperation with Developing Countries Final Report. Retrieved September 15, 2014 from coastalforests.tfcg.org/pubs/Char_Southern_Africa_

16. Datamania Consult (2014). Nigeria's Informal Sector Accounts for $\$ 178.5 b n$, 35\% of GDP. Retrieved from http://www.datamaniaconsult.com/nigerias-informal-sector-accounts-for-178-5bn-35-of-gdp/\#.WbLSvNC6zIU

17. DeFries, R. S., Rudel, T., Uriarte, M., Hansen, M. (2010). Deforestation driven by urban population growth and agricultural trade in the twenty-first century. Nat Geosci., 3, 178-181.

18. Egeru, A., S. (2014). Rural Households' Fuelwood Demand Determinants In Dryland Areas of Eastern Uganda A. S. Egeru. Energy Sources, Part B, 9,39-45.

19. Elebeke, E. (2012). SMEs contribute half of Nigeria's GDP. Retrieved from https://www.vanguardngr.com/2012/12/smes-contribute-half-of-nigerias-gdp/

20. Enterprise Baseline Survey $\quad$ Report (2012). $\quad$ Retrieved from http://www.sedinnigeria.net/images/documents/enterprise-baseline-survey-2012.pdf

21. Emejor, C. (2014) Nigeria: Informal Sector Accounts for 57.9 Percent of Nigeria's GDP. United Nations Development Programme. Retrieved from http://allafrica.com/stories/201406251007.html

22. Eweoya, O. A. (2006). Environmental impact of charcoal production and utilization in Ibarapa North Local government Area (Unpublished M.Sc. thesis Department of Urban and Regional Planning, University of Ibadan, Nigeria).

23. Falcão, M. P. (2005). Policy impact on stakeholder benefits and resource use and conservation in Mozambique: the case study of MOFLOR forest concession area and Pindanganga community area (Thesis presented for the degree of Ph.D. in Forestry at the University of Stellenbosch).

24. FAO (2016). Exportable Timber Resources of the British Colonial Territories. Unasylva, 1(2). Retrieved from www.energypedia.info

25. Food and Agricultural Organization (FAO) (1983). WoodFuel Surveys. GCP/INT/365/SWE.

26. Food and Agricultural Organization (FAO) (2005). Global Forest Resources Assessment: Progress Towards Sustainable Forest Management, Forestry (Paper 147). Retrieved from ftp.://fao.org/decrep/008/A0400E/A0400E00.pdf

27. Food and Agricultural Organization (n.d.). Exportable Timber Resources of the British Colonial Territories. Retrieved from http://www.fao.org/docrep/x5340e/x5340e0c.htm (accessed on April 28, 2016).

28. Food and Agriculture Organization (2008). Rapid Assessment of Pollinators' Status (64 p.). Retrieved November 16, 2013

http://www.bfn.delfileadmin/MDB/images/themen/bestaeuber/rapid_assessment_polinator_status.pdf

29. GIZ HERA (2016). Charcoal Production. GIZ HERA Cooking Energy Compedium. A practical guidebook for implementers of cooking energy interventions. Retrieved from https://energypedia.info/wiki/Charcoal Production

30. Habermehl, H. (2007). Economic evaluation of the improved household cooking stove dissemination programme in Uganda. The German Agency for Technical Cooperation (GTZ), Household Energy Programme - HERA. Retrieved from http://www.un.org/esa/sustdev/csd/csd15/lc/GTZ_Uganda.pdf

31. Hiproject (2017). Effects of Small Scale Business in the Development of Nigerian Economy. Retrieved from http://www.Iproject.Com.Ng/Installation/Index.Php/Purchasing-And-Supply/Effects-Of-Small-Scale-Business-InThe-Development-Of-Nigerian-Economy/Index.Html

32. International Labor Organization (2002). Women and Men in the Informal Economy: A Statistical Picture.

33. International Labor Organization (2003). Conclusions on Decent Work and the Informal Sector.

34. Jelili, M. O., Saliu, I., \& Falaye, A. (2015). Charcoal Production in Oriire Local Government Area, Oyo State, Nigeria: Environmental and Socio-Economic Questions. Civil and Environmental Research, 7(12), 21-28.

35. Kammen, D. M., \& Lew, D. J. (2005). Review of technologies for the production and use of charcoal. In Renewable and Appropriate Energy Laboratory report, Energy and Resources Group \& Goldman School of Public Policy (pp. 1-19). Berkeley, CA, USA: University of California.

36. Kuunibe, N., Issahaku, H., \& Nkegbe, P. K. (2013). Wood Based Biomass Fuel Consumption in The Upper West Region of Ghana: Implications for Environmental Sustainability. Journal of Sustainable Development Studies, $3(2), 181-198$.

37. Kwasi, O. A., Owusu, A., Imoro, B., \& Stephen, L. (2012). Commercial Charcoal Production and Sustainable Community Development of the Upper West Region, Ghana. Journal of Sustainable Development, 5(4), 149-164. 
38. Lacaux, J. P., Brocard, D., Lacaux, C., Delmas, R., Brou, A., Yobo V., Koffi, M. (1994). Traditional charcoal making; an important source of atmospheric pollution in the Africa tropic. Atmosphere Research, 35(1), 71.

39. Lew, J. D., Kammen, D. M. (1997). Review of social and environmental impacts of charcoal in Africa (120 p.). Woodrow Wilson School of Public and International Affairs, Princeton University, Princeton, NJ.

40. Luoga, E. J., Witkowski, E. T. F., \& Balkwill, K. (2000a). Economics of charcoal production in miombo woodlands of eastern Tanzania: some hidden costs associated with commercialisation of the resources. Ecological Economics, 35, 243-257.

41. May-Tobin, C. (2011). Wood for fuel. Union of concerned scientists, the root of the problem: what's driving tropical deforestation today? Retrieved from www.ucsusa.org/forests (accessed on September 10, 2017).

42. Mbisso, D. (2011). Petty Trading in Marketplaces: Space Generation, Use And Management at Temeke Stereo Marketplace in Dar es Salaam, Tanzania. Retrieved Http://Publications.Lib.Chalmers.Se/Records/Fulltext/154312.Pdf

43. Meathead (2011). Everything You Need to Know About Charcoal. Retrieved from http://www.huffingtonpost.com/craig-goldwyn/charcoal_b_858606.html

44. Meyers, M. (1985). The Gaia atlas of planet management. London: Gaia Books.

45. National Bureau of Statistics (2010). Nigeria poverty profile 2010. Retrieved from http://www.nigerianstat.gov.ng/pdfuploads/Nigeria\%20Poverty\%20Profile\%202010.pdf

46. National Population Commission (2006). Nigeria 2006 Census Figures. Retrieved from www.nigeriamasterweb.com/Nigeria06CensusFigs.html

47. National Population Commission (2016). Nigeria's population now 182 million. Retrieved from http://www.population.gov.ng

48. Nellemann, C., \& Corcoran, E. (Eds.) (2010). Dead planet, living planet-biodiversity and ecosystem restoration for sustainable development. A rapid response assessment. Arendal: United Nations Environment Programme, UNEP/GRID-Arendal.

49. Nyembe, M. (2011). An econometric analysis of factors determining charcoal consumption by urban households: the case of Zambia (Master's Thesis, Environmental Economics and Management, Uppsala, Sweden).

50. Okello, B. D.; O'Connor, T. G., \& Young, T. P. (2001). Growth, biomass estimates, and charcoal production of Acacia drepanolobium in Laikipia, Kenya. Forest Ecology and Management, 142(1-3), 143-153.

51. Oketola, D. (2016). From farm to dustbin: Plight of Nigerian farmers battling post -harvest losses. Retrieved from http://punchng.com/from-farm-to-dustbin/

52. Onoja, A. O., \& Idoko, O. (2012). Econometric Analysis of Factors Influencing Fuelwood Demand in Rural and Peri-urban Farm Households of Kogi State. The Journal of Sustainable Development, 8(1), 115-127.

53. Pari, L. (2000). ISMA system for mechanical harvesting of short rotation woody crops (SRWC). In S. Kyriotis, A. A. C. M. Beenackers, P. Helm, A. Grassi, D. Chiaramonti (Eds.), Proceedings of "Biomass for Energy and Industry”, 1st World Conference, Sevilla (pp. 1966-1970). James \& James, London.

54. Pennise, D. M., Smith, K. R., Kithinji, J. P., Rezende, M. E., Raad, T. J., Zhang, J. (2001). Emissions of greenhouse gases and other airborne pollutants from charcoal making in Kenya and Brazil. J Geophys Res, 106, 24143-24155.

55. Samuelson, P. A., \& Nordhaus, W. A. (2005). Economics. Tata Mc-Graw-Hill: New Delhi.

56. Sedano, F., Silva, J. A., Machoco, R., Meque, C. H., Sitoe, A., Ribeiro, N., Anderson, K., Ombe, Z. A., Baule, S. H., \& Tucker, C. J. (2016). The impact of charcoal production on forest degradation: a case study in Tete, Mozambique. Environ. Res. Lett. 11. doi:10.1088/1748-9326/11/9/094020

57. Small Starter Africa (2017). Business ideas, Inspiration and Success tips for African Entrepreneurs. Retrieved from http://www.smallstarter.com

58. Smith, K. R., Pennise, D. M., Khummongkol, P., Chaiwong, V., Ritgeen, K., \& Zhang, J. (1999). Greenhouse gases from small-scale combustion in developing countries: charcoal-making kilns in Thailand (Report EPA600/R-99-109). Research Triangle Park, N.C.: U.S. Environmental Protection Agency.

59. Stassen, H. E. (2002). Nuevas tecnologias de produccion de carbon vegetal. Unasylva, 211(53), 34-35.

60. Trading Economics (n.d.). Nigeria GDP per capita. Retrieved from https://tradingeconomics.com/nigeria/gdp-percapita (accessed on September 10, 2017).

61. UN-Habitat (2009). Global Report on Human Settlements 2009. London: Earthscan.

62. Ward, D. E., Chidumayo, E., Baker, S. P., \& Susott, R. A. (1999). Charcoal production and smoke emissions from earthen kilns in Zambia (Final report submitted to Environmental Research Laboratory, 1 College Station Road, Atthens, GA, USA).

63. Waters, J. (2015). Charcoal has become the hot new flavouring in everything from cocktails to meat and mash. Retrieved from http://www.independent.co.uk/life-style/food-and drink/features/charcoal-has-become-the-hotnew-flavouring-in-everything-from-cocktails-to-meat-and-mash-10166230.html

64. World Agroforestry Centre Fact Sheet (n.d.). Charcoal: A driver of dryland forest degradation in Africa? Retrieved from www.worldagroforestry.org

65. Worldatlas (2018). Top 10 Wood Charcoal Producing Countries. Retrived from https://www.worldatlas.com/articles/top-10-wood-charcoal-producing-countries.html 